\title{
Carbohydrate levels in the leaves and production consistency of the Ponkan tangerine when thinned out with Ethephon ${ }^{1}$
}

\author{
Teores de carboidratos nas folhas e regularidade da produção de tangerineira \\ 'Ponkan' raleadas com Ethephon
}

\author{
Rodrigo Amato Moreira ${ }^{2 *}$, José Darlan Ramos², Maria do Céu Monteiro da Cruz ${ }^{3}$, Lílian de Araújo Pantoja ${ }^{4}$ e \\ Alexandre Soares dos Santos ${ }^{5}$
}

\begin{abstract}
Management practices that maintain carbohydrate reserves in tangerines are necessary in order to ensure good yields. This experiment was carried out with the object of evaluating the levels of carbohydrates in the leaves, and consistency in the production of the Ponkan tangerine (Citrus reticulata Blanco) when subjected to chemical thinning with five concentrations of Ethephon for three consecutive years. The Ponkan tangerine evaluated had been grafted onto Rangpur lime (Citrus limonia Osbeck), cultivated with a spacing of 6.0 x $3.0 \mathrm{~m}$ and were 12 years old. The Ethephon concentrations tested were: 0; 200; 400; 600 and $800 \mathrm{mg} \mathrm{L}^{-1}$, applied in January of 2009; 2010 and 2011, when the fruits were of 25 to $30 \mathrm{~mm}$ in transverse diameter. The experimental design was of randomized blocks, with four blocks and four plants per plot. The levels of soluble leaf carbohydrate, starch and total carbohydrates were evaluated during flowering and harvesting. Fifteen days after application of the concentrations, the percentage of thinning was evaluated. Production, pending load and alternate bearing were evaluated when harvesting. Chemical thinning with Ethephon favors the maintaining of leaf carbohydrates in the Ponkan tangerine. The most effective concentration in reduncing the alternate bearing in the Ponkan tangerine is $600 \mathrm{mg} \mathrm{L}^{-1}$ of Ethephon.
\end{abstract}

Key words: Citrus reticulata Blanco. Chemical thinning. Alternate bearing. Ethylene.

\begin{abstract}
RESUMO - Práticas de manejo que proporcionem a manutenção das reservas de carboidratos nas tangerineiras são necessárias para garantir boas produtividades. O experimento foi conduzido com o objetivo de avaliar os teores de carboidratos foliares e a regularidade da produção de tangerineira 'Ponkan' (Citrus reticulata Blanco) submetida ao raleio químico com cinco concentrações de Ethephon por três anos consecutivos. As tangerineiras 'Ponkan' avaliadas estavam enxertadas sobre limoeiro 'Cravo' (Citrus limonia Osbeck), cultivadas no espaçamento 6,0 x 3,0 m e com 12 anos de idade. As concentrações de Ethephon testadas foram: 0; 200; 400; 600 e $800 \mathrm{mg} \mathrm{L}^{-1}$, aplicadas quando as frutas estavam com 25 a $30 \mathrm{~mm}$ de diâmetro transversal, nos meses de janeiro de 2009, de 2010 e de 2011. O delineamento experimental utilizado foi em blocos casualizados, com quatro blocos e quatro plantas por parcela. Foram avaliados os teores foliares de carboidratos solúveis, de amido e de carboidratos totais nos períodos de floração e de colheita. Após 15 dias da aplicação das concentrações avaliou-se o percentual de raleio. Nas colheitas foram avaliadas a produção, a carga pendente e a alternância de produção. O raleio químico com Ethephon favorece a manutenção dos teores de carboidratos foliares na tangerineira 'Ponkan'. A concentração mais eficiente para reduzir a alternância de produção em tangerineiras 'Ponkan' é $600 \mathrm{mg} \mathrm{L}^{-1}$ de Ethephon.
\end{abstract}

Palavras-chave: Citrus reticulata Blanco. Raleio químico. Alternância de produção. Etileno.

\footnotetext{
*Autor para correspondência

'Recebido para publicação em 01/06/2012; aprovado 29/01/2013

Parte da Tese de Doutorado apresentada ao Programa de Pós-Graduação em Agronomia/Fitotecnia da Universidade Federal de Lavras/UFLA 2Departamento de Agricultura, Universidade Federal de Lavras/UFLA, Lavras-MG, Brasil, amatomoreira @yahoo.com.br, darlan@dag.ufla.br ${ }^{3}$ Departamento de Agronomia, Universidade Federal dos Vales do Jequitinhonha e Mucuri/UFVJM, Dimantina-MG, Brasil, mariceu@ufvjm.edu.br ${ }^{4}$ Departamento de Engenharia de Alimentos, Universidade Federal dos Vales do Jequitinhonha e Mucuri/UFVJM, Diamantina-MG, Brasil, 1.pantoja@ufvjm.edu.br

${ }^{5}$ Departamento de Química, Universidade Federal dos Vales do Jequitinhonha e Mucuri/UFVJM, Diamantina-MG, Brasil, alexandre.soares@ufvjm.edu.br
} 


\section{INTRODUCTION}

Alternate bearing, characterized by excessive fruit production interspersed with years of low or no production, is a recurring problem in the Ponkan tangerine (MAIA; SIQUEIRA; CECON, 2010; MOREIRA et al., 2011a; RUFINI; RAMOS, 2002), with depletion of the plant reserves, mainly carbohydrates which accumulate in the root system and the leaves (GOLDSCHMIDT; $\mathrm{KOCH}, 1996$ ), occurring in the year of high production, compromising production of the next crop.

Carbohydrate reserves are used in the formation and development of the flowers and fruit of citrus trees (CRUZ et al., 2007; MONERRI et al., 2011; RUIZ et al., 2001). During this stage, the demand for carbohydrates in the plants is high, due to the excessive amount of flowers formed by the tangerine, surpassing the daily production of carbohydrates by the leaves (BUSTAN; GOLDSCHMIDT, 1998).

Management practices that provide for the maintaining of carbohydrate reserves in the plants are crucial to ensure uniform flowering the following year, and economically viable yields of the Ponkan tangerine (MOREIRA et al., 2011b). Among such practices, chemical thinning with Ethephon stands out for affording fruit abscission, reducing the competition between fruits and an improvement in fruit size (CRUZ et al., 2009, 2010a, 2010b, 2011; MOREIRA et al., 2012; RAMOS et al., 2009).

The results of the application of Ethephon on alternate bearing in citrus plants are variable and depend on when the plants are thinned, on the tangerine cultivar, and on the interaction with the environmental conditions. In the Montenegrina tangerine (Citrus deliciosa Tenore), this alternation was reduced with the use of $200 \mathrm{mg} \mathrm{L}^{-1}$ Ethephon $+3 \%$ urea (SOUZA et al., 1993). However, Sartori et al. (2007), working with the same cultivar observed no effect when applying $200 \mathrm{mg} \mathrm{L}^{-1}$ Ethephon.

Given the above, an experiment was carried out with the object of evaluating the levels of carbohydrates in the leaves, and consistency in the production of the Ponkan tangerine when subjected to chemical thinning with five concentrations of Ethephon for three consecutive years.

\section{MATERIAL AND METHODS}

This experiment was carried out from October 2008 to June 2011, in the agricultural seasons of 2008/2009, 2009/2010 and 2010/2011, in a commercial orchard of 12-year-old, nonirrigated Ponkan tangerine (Citrus reticulata Blanco) grafted onto 'Rangpur' lime (Citrus limonia Osbeck), cultivated with a spacing of $6.0 \times 3.0 \mathrm{~m}$.

The location for the experiment was at Perdões, in southern Minas Gerais, Brazil, situated at Latitude $21^{\circ} 05^{\prime} 27^{\prime \prime} \mathrm{S}$ and Longitude $45^{\circ} 05^{\prime} 27^{\prime \prime} \mathrm{W}$, having a type Cwb climate according to the Köppen classification, characterized by hot, humid summers and dry, cold winters. Temperature variations, precipitation and relative humidity during the experiment are shown in Figure 1.

The concentrations used to carry out thinning were $0 ; 200 ; 400 ; 600$ and $800 \mathrm{mg} \mathrm{L}^{-1}$ of Ethephon, after the period of physiological fruit drop, when these were in the stage of development of 25 to $30 \mathrm{~mm}$ in transverse diameter, in January 2009, 2010 and 2011. The experimental design was of randomized blocks, with four blocks and four plants per plot.

Before the application of the treatments, plants with abundant flowering throughout the crown were selected, so that all could present significant amounts of fruit, and be in similar condition regarding the availability and consumption of their reserves at the start of chemical thinning. In the second and third year, the same concentrations were applied to those plants which had been sprayed the first year, thus enabling evaluation of yield behaviour as regards plant reserves and the regularity of thinning.

The plants were sprayed over the full extent of the crown, to provide homogeneous wetting, with approximately two liters of solution, as previously determined in a trial test using water. The commercial product Ethrel $®$ was used, a soluble concentrate containing $240 \mathrm{~g} \mathrm{~L}^{-1}$ of 2-chloroethyl phosphonic acid (Ethephon), applied with the adhesive spreader WIL FIX $®$, employing a spray with a conical nozzle and a capacity for particle deposition of about 70 to 100 drops $\mathrm{cm}^{-2}$, with diameters of 100-200 microns at a pressure of $6 \mathrm{kgf} \mathrm{cm}^{-2}$.

Cultivation, fertilization, and pest and disease control were carried out throughout the experimental period, following the recommendations for tangerine crops.

To determine the leaf content for soluble carbohydrates $\left(\mathrm{mg} \mathrm{g}^{-1}\right)$, starch $\left(\mathrm{mg} \mathrm{g}^{-1}\right)$ and total carbohydrates $\left(\mathrm{mg} \mathrm{g}^{-1}\right), 48$ mature leaves from productive branches were collected per plot during the periods of flowering (October 2009, 2010 and 2011) and harvesting (June 2009; 2010 and 2011).

After sampling, the leaves were washed in distilled water and placed in a forced-air oven at $65^{\circ} \mathrm{C}$ for 72 hours, when they reached constant mass. Then the extracts were prepared from $40 \mathrm{mg}$ of macerated leaves using an alcohol solution $(80 \% \mathrm{v} / \mathrm{v})$ for soluble sugars, and perchloric acid $(30 \% \mathrm{v} / \mathrm{v})$ for starch. Analyses were carried out using the Antrona method, in accordance with the methodology proposed by McCready et al. (1950).

For each tree, two branches were marked in order to determine the percentage of thinning by counting the fruits on the days of application and those that remained 15 days 
Figure 1 - Average monthly precipitation $(\mathrm{mm})$, maximum temperature $\left({ }^{\circ} \mathrm{C}\right)$, average temperature $\left({ }^{\circ} \mathrm{C}\right)$, minimum temperature $\left({ }^{\circ} \mathrm{C}\right)$ and relative humidity (\%) during the experimental period, in the region of Perdões, Minas Gerais, Brazil

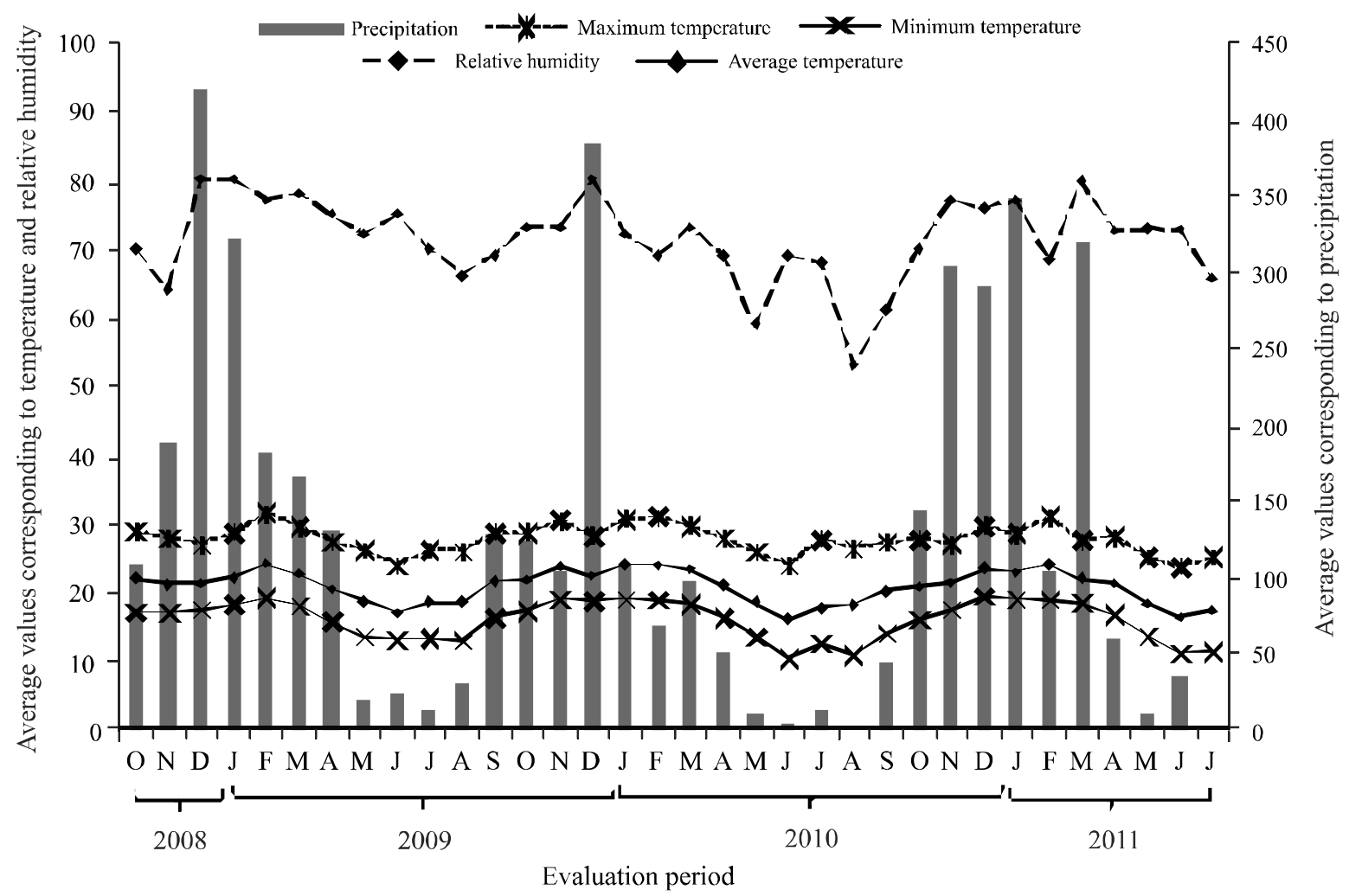

after spraying, for the three years evaluated. The fruit fall in the plants having stopped during this period.

In the harvests which took place in June 2009, June 2010 and June 2011, production (boxes of $22 \mathrm{~kg} \mathrm{plant}^{-1}$ ) and pending load $\left(\mathrm{kg} \mathrm{plant}^{-1}\right)$ were evaluated. The pending load consisted of fruits that did not come up to the commercial standard (COMPANHIA DE ENTREPOSTOS E ARMAZÉNS GERAIS DE SÃO PAULO, 2000), that is fruits with less than 58 and $60 \mathrm{~mm}$ longitudinal and transverse diameter respectively.

At the time of each harvest, to calculate the percentage of alternate bearing, the number of plants with low or no production was evaluated.

Data were subjected to variance analysis and polynomial regression for model adjustment, at 5\% probability of error.

\section{RESULTS AND DISCUSSION}

There was a triple interaction for the leaf carbohydrate levels between Ethephon concentrations, years of evaluation and sampling period of the leaves (Table 1).
Table 1 - Summary of the variance analysis for leaf carbohydrate levels in the Ponkan tangerine for sampling times (flowering and harvest) when exposed to different concentrations of Ethephon in the three years under evaluation, at Perdões, Minas Gerais, Brazil

\begin{tabular}{lcrr}
\hline \multirow{2}{*}{ SV } & \multirow{2}{*}{ GL } & \multicolumn{2}{c}{ MEAN SQUARE } \\
\cline { 3 - 4 } & & \multicolumn{1}{c}{ SO } & \multicolumn{1}{c}{ ST } \\
\hline ETHE & 4 & $5.752,00^{*}$ & $951,20^{*}$ \\
BLOCK & 3 & $98,99^{*}$ & $13,84^{\mathrm{ns}}$ \\
ETHE*EPOC & 4 & $503,48^{*}$ & $114,80^{*}$ \\
EPOC & 1 & $12.381,40^{*}$ & $1.872,69^{*}$ \\
ERROR1 & 83 & 12,32 & 9,20 \\
YEAR & 2 & $14.305,40^{*}$ & $560,82^{*}$ \\
ETHE*EPOC *YEAR & 8 & $908,70^{*}$ & $117,31^{*}$ \\
ETHE*YEAR & 8 & $359,60^{*}$ & $175,50^{*}$ \\
EPOC*YEAR $^{*}$ & 2 & $5.588,84^{*}$ & $327,44^{*}$ \\
ERROR2 $^{*}$ YV & 3,19 & 9,80 \\
CV $_{1}(\%)$ & 4 & 5,2 & 9,6 \\
CV $_{2}(\%)$ & & 2,7 & 9,9 \\
\hline
\end{tabular}

SV - Sources of variation; ETHE - Ethephon concentration; EPOC - Period of leaf sampling, SO - Leaf soluble carbohydrates levels $\left(\mathrm{mg} \mathrm{g}^{-1}\right)$; ST - Leaf starch levels $\left(\mathrm{mg} \mathrm{g}^{-1}\right)$, ns - not significant , ${ }^{*}$ - significant at $5 \%$ by the F-test 
At the start of the experiment, plants were selected for potential yield in order for them to be under similar conditions at the time of application of the treatments, this being confirmed by the results obtained at flowering (2008/2009), where it was seen that those plants subjected to thinning had similar levels of soluble sugars (34.11 $\mathrm{mg} \mathrm{g}^{-1}$ ) and starch (24.45 $\mathrm{mg} \mathrm{g}^{-1}$ ) (Figures 2A and 3A).

At harvest time in the first growing season after thinning (2008/2009), it was found that applied concentrations of Ethephon influenced the levels of carbohydrates in the leaves, since a linear increase was observed in the levels of soluble carbohydrates in plants treated with Ethephon at the concentration of $800 \mathrm{mg} \mathrm{L}^{-1}$ (Figure 2B). Levels of starch did not differ between treatments (Figure 3B). This behavior may be due to the conversion of carbohydrate reserves (starch) to soluble sugars, caused by the demand for fruit development (CRUZ et al., 2007; MONERRI et al., 2011).

In the second year (2009/2010), linear increases were observed for leaf soluble carbohydrates and starch

Figure 2 - Polynomial regressions of leaf soluble sugar levels: during flowering (A) and at harvest (B) for the Ponkan tangerine, against concentrations of Ethephon, for the three years evaluated, in Perdões, Minas Gerais, Brazil

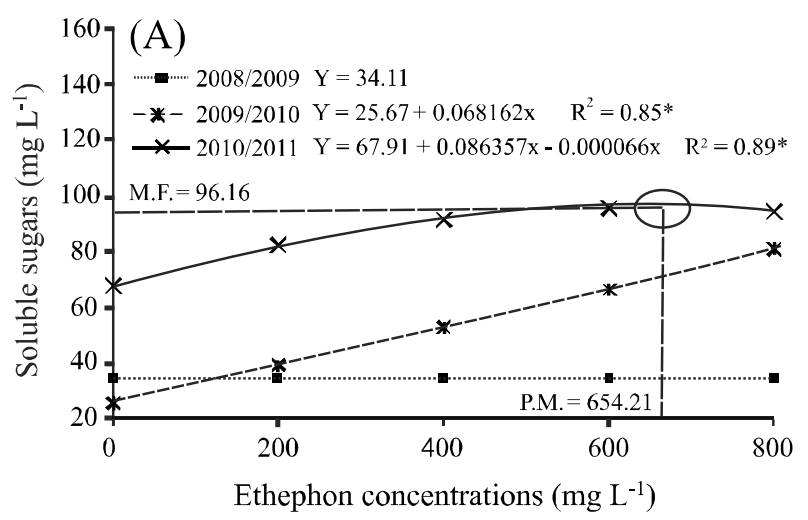

(B)

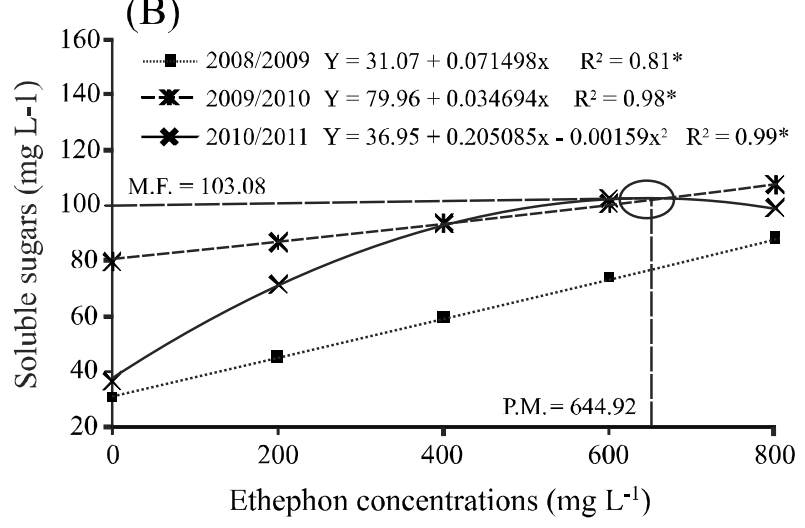

$* \mathrm{P}<0.05$ by the $\mathrm{t}$-test
Figure 3 - Polynomial regressions of leaf starch levels: during flowering (A) and at harvest (B) for the Ponkan tangerine, against concentrations of Ethephon, for the three years evaluated, in Perdões, Minas Gerais, Brazil
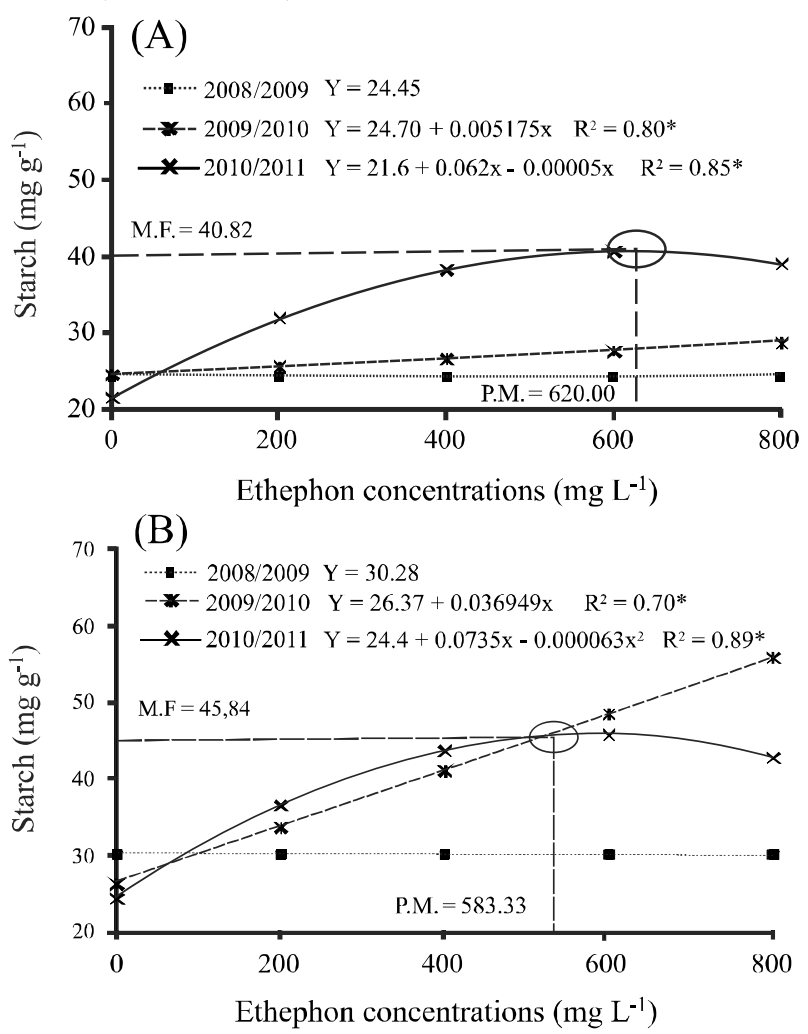

$* \mathrm{P}<0.05$ by the $\mathrm{t}$-test

related to the concentrations of Ethephon during flowering and at harvest time. Whereas in the third year (2010/2011) the behavior observed for the levels of leaf carbohydrates was quadratic in both of the periods studied (Figures 2 and 3). During flowering, the maximum levels of leaf soluble sugars were observed in those plants sprayed with the estimated concentration of $654.21 \mathrm{mg} \mathrm{L}^{-1}$ Ethephon, and at harvest time, of $644.92 \mathrm{mg} \mathrm{L}^{-1}$ Ethephon (Figures 2A and 2B ). For leaf starch levels, behavior was similar, with the highest values estimated during flowering in those plants that received a concentration of $620.00 \mathrm{mg} \mathrm{L}^{-1}$ Ethephon, and at harvesting of $583.33 \mathrm{mg} \mathrm{L}^{-1}$ Ethephon.

Levels of total leaf carbohydrates at harvest time were greater than at flowering for all concentrations used (Figure 4). This behavior may be attributed to the greater consumption of carbohydrates that occurs at flowering in citrus plants in order to form both vegetative and flowering shoots (CRUZ et al., 2007; MONERRI et al., 2011; RUIZ et al., 2001). After the period of natural abscission, in addition to the lower demand for carbohydrates by the fruits, transport from the roots to 
Figure 4 - Average total leaf carbohydrate levels in the Ponkan tangerine when sprayed with different concentrations of Ethephon (0; 200; 400; 600 and $\left.800 \mathrm{mg} \mathrm{L}^{-1}\right)$ for periods of evaluation, in Perdões, Minas Gerais, Brazil

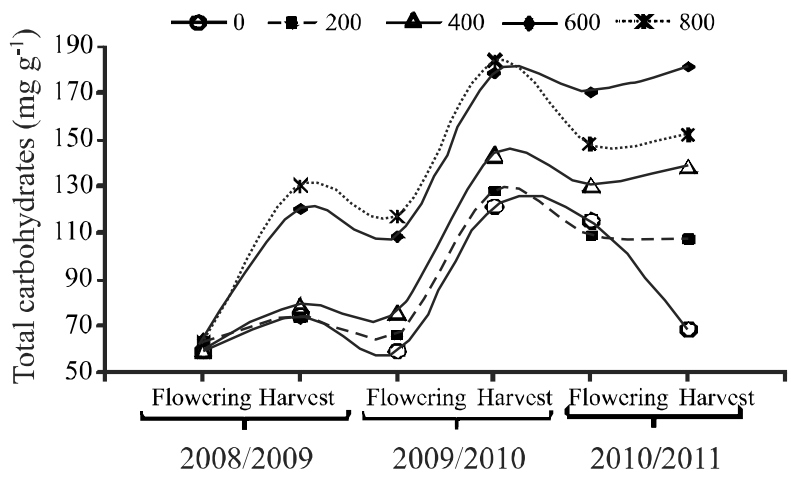

the leaves (MEHOUACHI et al., 2009) and an increase in the rates of photosynthesis during the summer can occur (PEREIRA et al., 2011), which results in the accumulation of starch in the leaves at harvest time.

The observed behavior in relation to carbohydrate levels possibly occurred due to chemical thinning, which because of fruit abscission, allowed for an increase in the source, in relation to the sink, (GUARDIOLA; GARCÍALUIZ, 2000), and favouring the availability of carbohydrates in the leaves due to the lesser use by the fruit.

For the variables: percentage of thinning, yield and pending load, significant interaction was found between the concentrations of Ethephon and the year of assessment, as shown in Table 2.

Alinear increase in the percentage of thinning in terms of Ethephon concentrations was seen (Figure 5). In plants

Table 2 - Summary of variance analysis for the agronomic variables of the Ponkan tangerine subjected to different concentrations of Ethephon, for the three years evaluated, in Perdões, Minas Gerais, Brazil

\begin{tabular}{lcccc}
\hline \multirow{2}{*}{ SV } & \multirow{2}{*}{ GL } & \multicolumn{3}{c}{ MEAN SQUARE } \\
\cline { 3 - 5 } & & YD & PL & TH \\
\hline ETHE & 4 & $2,89^{*}$ & $36,64^{*}$ & $1224,87^{*}$ \\
BLOCK & 3 & $5,59^{*}$ & $5,21^{\text {ns }}$ & $9,86^{\text {ns }}$ \\
ERROR1 & 12 & 0,80 & 3,16 & 29,43 \\
ETHE*YEAR & 8 & $2,39^{*}$ & $14,60^{*}$ & $234,43^{*}$ \\
YEAR & 2 & $19,75^{*}$ & $61,11^{*}$ & $704,08^{*}$ \\
ERROR2 & 30 & 0,66 & 9,16 & 62,29 \\
CV $_{1}(\%)$ & & 24,4 & 25,7 & 48,3 \\
CV $_{2}(\%)$ & & 22,3 & 23,4 & 70,2 \\
\hline
\end{tabular}

SV - Sources of variation; ETHE - Ethephon concentration; YD - Yield (22 kg boxes per plant); PL - Pending load (kg per plant); TH - Thinning; $(\%) ;{ }^{\text {ns }}$ - not significant,$*$ - significant at $5 \%$ by the F-test that were subjected to $800 \mathrm{mg} \mathrm{L}^{-1}$, for the agricultural years 2008/2009, 2009/2010 and 2010/2011 thinning of $28.5,7.0$ and 40.0 respectively was observed. This difference in thinning between years can be attributed to the amount of fruit produced by the plants, since the action of Ethephon on thinning intensity is proportional to the amount of fruit on the plant (MOREIRA et al., 2011a, 2012).

Figure 5 - Polynomial regressions of percentage fruit thinning of the Ponkan tangerine against concentrations of Ethephon, for the three years evaluated, in Perdões, Minas Gerais, Brazil

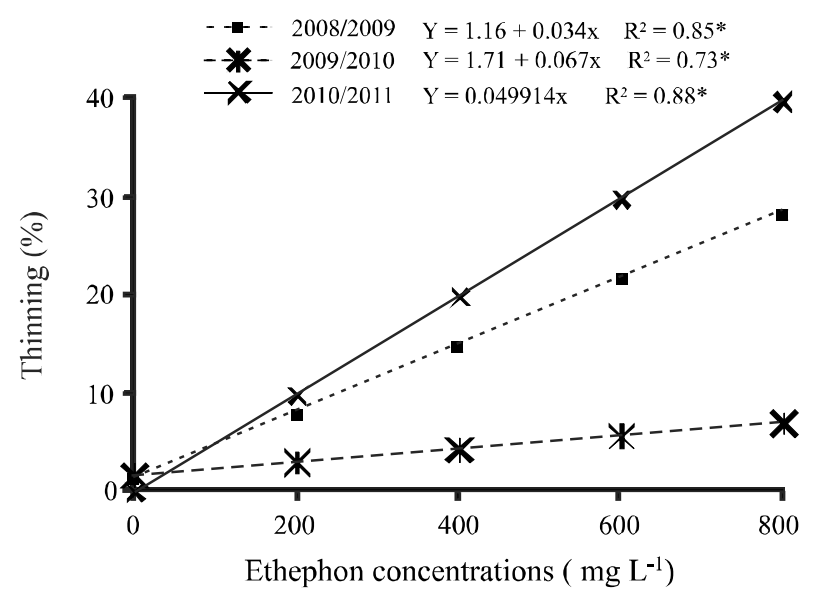

$* \mathrm{P}<0.05$ by the t-test

It is worth noting that in those tangerines sprayed with $800 \mathrm{mg} \mathrm{L}^{-1}$ Ethephon, intense leaf abscission was observed, perhaps being explained by the higher level of ethylene released by this concentration promoting abscission of the reproductive organs (IGLESIAS et al., 2006) and also of vegetation such as leaves, due to the increased cellulase activity in the abscission zone of theses organs (GUAN et al., 1995).

For the crop yield of the 2008/2009 harvest, there were no significant differences in production between plants sprayed with different concentrations of Ethephon, with an average production of 4.62 boxes of $22 \mathrm{~kg}$ per plant (Figure 6A). This was because at the time of flowering in that agricultural year, all the plants, irrespective of treatment, had similar carbohydrate levels and after thinning, a reduction of $28.5 \%$ in the number of fruits per plant was offset by the number of larger fruit, this being due to the increase in source against sink (GUARDIOLA; GARCIA- LUIZ, 2000). Meanwhile, for the control plants, some yield showed reduced size, and remained on the plant as pending load (Figure 6B). Thus the lower number of fruits on those plants sprayed with the highest concentrations of Ethephon did not reduce yield. 
Figure 6 - Polynomial regression of production (A) and pending load (B) for fruit of the Ponkan tangerine against Ethephon concentrations, for the three years evaluated, in Perdões, Minas Gerais, Brazil
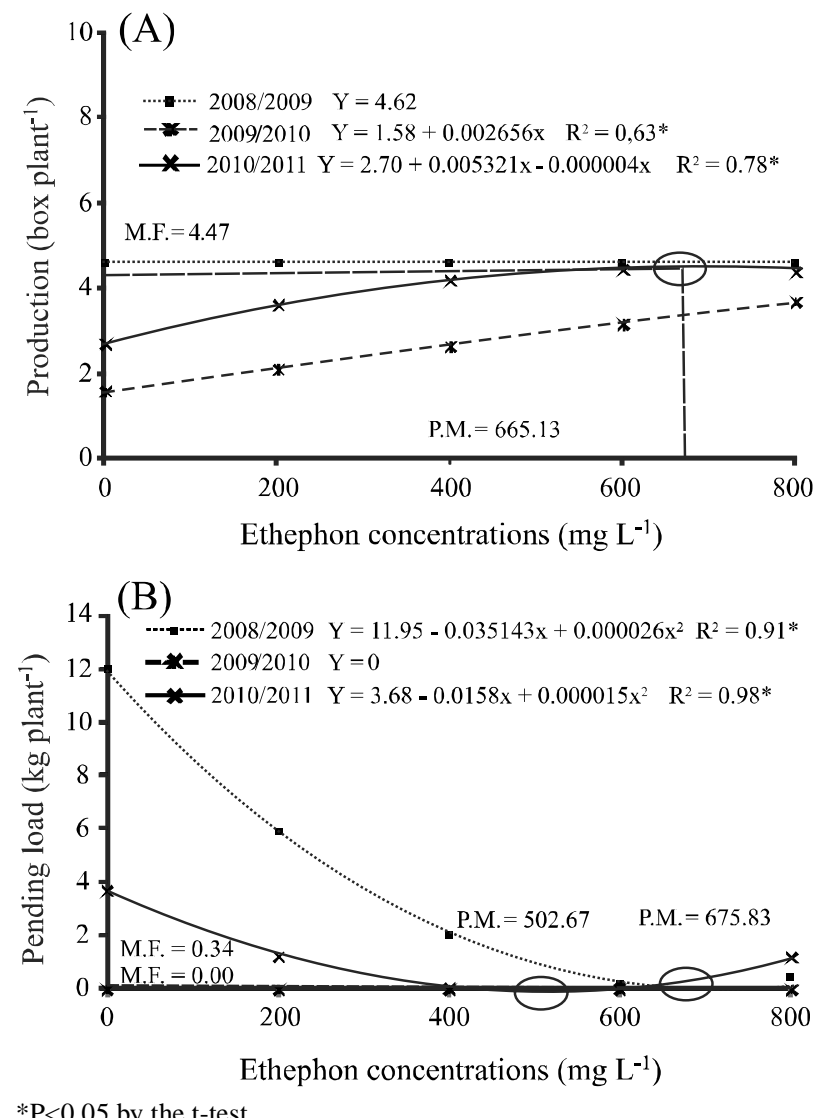

$* \mathrm{P}<0.05$ by the t-test

The concentration of $800 \mathrm{mg} \mathrm{L}^{-1}$ in 2009/2010 resulted in a $97.1 \%$ increase in production when compared to the control plants. Just one year later, in 2010/2011, the maximum estimated production of 4.47 boxes of $22 \mathrm{~kg}$ per plant was observed, representing an increase of $65.6 \%$ at the concentration of $665.13 \mathrm{mg} \mathrm{L}^{-1}$ compared to those plants that were not sprayed with Ethephon (Figure 6A). These results corroborate the $81 \%$ increase in production achieved for commercial grade Ponkan tangerines with $600 \mathrm{mg} \mathrm{L}^{-1}$ Ethephon (CRUZ et al., 2011).

The difference in relation to production highlights the importance of carbohydrates in reducing alternate bearing in the second year after completion of thinning, especially in those plants sprayed with $600 \mathrm{mg} \mathrm{L}^{-1}$ (Figure 7). These results can be explained by the maintenance of high levels of carbohydrates in these plants compared to other treatments; this not being observed in the first year because of the plants having been selected for productive potential and therefore being under similar conditions, and also in the third year (2010/2011), due to alternate bearing, which
Figure 7 - Mean percentage values of alternate bearing in the Ponkan tangerine against Ethephon concentrations, for 2009/2010, in Perdões, Minas Gerais, Brazil

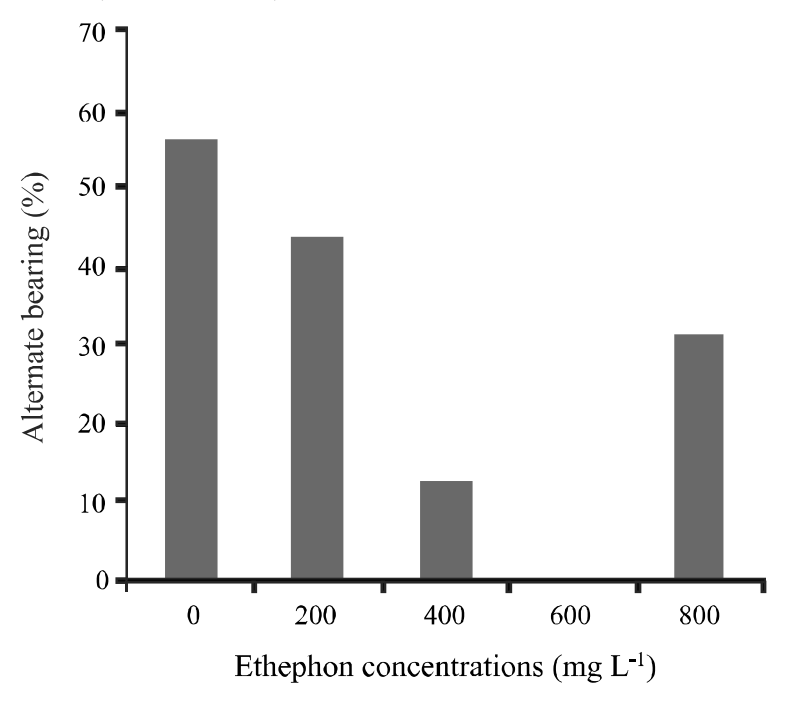

meant higher levels of carbohydrates than at flowering in the year 2009/2010. This occurs because in the year in which the harvest is smaller, the roots accumulate high amounts of reserves, favoring greater flowering and fixation of fruit the following year (AGUSTÍ, 2000).

The low yield evaluated in the plants not sprayed with Ethephon and those sprayed with the lowest concentration (200 $\mathrm{mg} \mathrm{L}^{-1}$ ) for the year 2009/2010, can be attributed to the higher alternate bearing observed that year, probably occurring as a result of the consumption of the carbohydrate reserves accumulated in the root system and in the leaves (GOLDSCHMIDT; KOCH, 1996) due to increased competition between the fruits that remained on the plants. Sartori et al. (2007) also showed that the concentration of $200 \mathrm{mg} \mathrm{L}^{-1}$, Ethephon did not produce a thinning effect nor reduced alternate bearing in the Montenegrina tangerine.

The reduction in alternate bearing for the second year of harvest, and the increase in production in subsequent years $(2009 / 2010 ; 2010$ and 2011) related to Ethephon concentrations, can be correlated with the greater accumulation of assessed leaf carbohydrates in those plants subjected to chemical thinning. It is known that carbohydrates are used in the formation and development of the flowers and fruit of citrus trees (CRUZ et al., 2007; MONERRI et al., 2011; RUIZ et al., 2001) and that the total carbohydrate demand by the flower during anthesis exceeds the daily carbohydrate production of the leaf (BUSTAN; GOLDSCHMIDT, 1998), with higher levels being necessary before flowering in order to allow for fixation of the flowers and fruits and avoid alternate bearing. 
Another relevant aspect in relation to the thinning effect, used to minimize the occurrence of alternate bearing, is the establishment of the correct concentrations, since those plants sprayed with a concentration of $800 \mathrm{mg} \mathrm{L}^{-1}$ also showed alternate bearing. This behavior demonstrates that plants subjected to thinning at high concentrations may be unable to regulate yield due to the leaf abscission recorded in these plants, or stress may be caused, promoting a reduced total carbohydrate content (Figure 4). Leaf abscission was also reported in other experiments in which this concentration of Ethephon was used (MOREIRA et al., 2011a, 2011b).

\section{CONCLUSIONS}

1. Chemical thinning with Ethephonfavors the maintenance of leaf carbohydrate levels in the Ponkan tangerine;

2. A concentration of $600 \mathrm{mg} \mathrm{L}^{-1}$ Ethephon is the most efficient in reducing alternate bearing in the Ponkan tangerine.

\section{ACKNOWLEDGEMENT}

The authors wish to thank 'Conselho Nacional de Desenvolvimento Científico e Tecnológico' (CNPq) and 'Coordenação de Aperfeiçoamento de Pessoal de Nível Superior' (CAPES) for the scholarships granted.

\section{REFERENCES}

AGUSTÍ, M. Citricultura. Madrid: Mundi-Prensa, 2000. 416 p.

BUSTAN, A.; GOLDSCHMIDT, E. E. Estimating the cost of flowering in a grapefruit tree. Plant Cell and Environment, v. 21 , n. 2 , p. $217-224,1998$

COMPANHIA DE ENTREPOSTOS E ARMAZÉNS GERAIS DE SÃO PAULO. Classificação das tangerinas. São Paulo: Centro de Qualidade de Horticultura, 2000. Fôlder.

CRUZ, M. C. M. et al. Teores de carboidratos em limeiras ácidas 'Tahiti' tratadas com paclobutrazol. Revista Brasileira de Fruticultura, v. 29, n. 2, p. 222-226, 2007.

CRUZ, M. C. M. et al. Qualidade de frutas de tangerineira 'Ponkan' submetidas ao raleio químico. Revista Brasileira de Fruticultura, v. 31, n. 1, p. 127-134, 2009.

CRUZ, M. C. M. et al. Características físico-químicas da tangerina 'Ponkan' submetida ao raleio químico em relação à disposição na copa. Ciência e Agrotecnologia, v. 34, n. 1, p. 37-42, 2010a.

CRUZ, M. C. M. et al. Crescimento de tangerinas 'Ponkan' em plantas submetidas ao raleio químico. Revista Ceres, v. 57, n. 4, p. 500-505, 2010b.

CRUZ, M. C. M. et al. Raleio químico na produção de tangerina 'Ponkan'. Revista Brasileira de Fruticultura, v. 33, n. 1, p. 279-285, 2011.
GUARDIOLA, J. L.; GARCÍA-LUIZ, A. Increase size in citrus: thinning and stimulation of fruit growth. Plant Growth Regulation, v. 31, n. 1/2, p. 121-132, 2000.

GOLDSCHMIDT, E. E.; KOCH, K. E., Citrus. In: ZAMSKI, E.; SCHAFFER, A. A. (Ed.), Photoassimilate Distribution in Plants and Crops. New York: Marcel Dekker Inc., 1996. p. 797-823.

GUAN, Y. L. et al. Hormonal control of abscission of young citrus fruits. Acta Agriculturae Zhejiangensis, v. 7, n. 4, p. 297-300, 1995.

IGLESIAS, D. J. et al. Carbohydrate and ethylene levels regulate citrus fruitlet drop through the abscission zone A during early development. Trees: Structure and Function, v. 20, p. 348-355, 2006.

MAIA,E.;SIQUEIRA,D.L.; CECON,P.R. Produção, florescimento e frutificação de tangerineira 'Poncã' submetida à aplicação de ácido giberélico. Ciência Rural, v. 40, n. 3, p. 507-512, 2010.

MCCREADY, R. M. et al. Determination of Starch and Amylose in Vegetables. Analytical Chemistry, v. 22, n. 9, p. 1156-1158, 1950.

MEHOUACHI, J. et al. Delay of early fruitlet abscisión by Branco girdling in Citrus coincides with previous increases in carbohydrate and gibberelin concentrations. Plant Groth Regulation, v. 58, p. 15-23, 2009.

MONERRI, C. et al. Relation of carbohydrate reserves with the forthcoming crop, flower formation and photosynthetic rate, in the alternate bearing 'Salustiana' sweet orange (Citrus sinensis L.). Scientia Horticulturae, v. 129, n. 1, p.71-78, 2011.

MOREIRA, R. A. et al. Regularidade da produção de tangerineiras 'Ponkan' submetidas ao raleio químico bianual. Revista Brasileira de Fruticultura, v. 33, p. 235-240, 2011a.

MOREIRA, R. A. et al. Production of 'Ponkan' mandarin trees submitted to chemical thinning. Agrária, v. 6, n. 2, p. 287-291, 2011b.

MOREIRA, R. A. et al. Qualidade de tangerinas 'Ponkan' em função da regularidade do raleio químico. Pesquisa Agropecuária Tropical, v. 42, n. 3, p. 303-309, 2012.

PEREIRA, C. S. et al. Teores de carboidratos nas folhas e produção de limeiras ácida 'Tahiti' aneladas e tratadas com ácido giberélico. Revista Brasileira de Fruticultura, v. 33, n. 3, p. 706-712, 2011.

RAMOS, J. D. et al. Etephon no raleio de tangerinas 'Ponkan. Ciência Rural, v. 39, n. 1, p. 236-240, 2009.

RUFINI, J. C. M.; RAMOS, J. D. Influência do raleio manual sobre a qualidade dos frutos da tangerineira 'Ponkan' (Citrus reticulata Blanco). Ciência e Agrotecnologia, v. 26, n. 3, p. 516-522, 2002.

RUIZ, R. et al. Carbohydrate availability in relation to fruitlet abscission in Citrus. Annals of Botany, v. 87, p. 805-812, 2001.

SARTORI, I.A. et al. Efeito da poda, raleio de frutos e uso de fitorreguladores na produção de tangerinas (Citrus deliciosa Tenore) cv. Montenegrina. Revista Brasileira de Fruticultura, v. 29, n. 1, p. 5-10, 2007.

SOUZA, P. V. D. et al . Influência de concentrações de etefon e pressões de pulverização foliar sobre a produção de frutos e o teor de substâncias de reserva em tangerineiras. Pesquisa Agropecuária Brasileira, v. 28, n. 5, p. 613-619, 1993. 